\title{
A brief analysis on the embodiment of practical teaching module of undergraduate financial Management major in talent cultivation scheme Take Xi'an traffic engineering institute for example
}

\author{
Xiaoli Liu ${ }^{1, \mathrm{a}}$, Haixiang $\mathrm{Li}^{1, \mathrm{~b}}$, Zhe Chen ${ }^{1, \mathrm{c}}$, Huanhuan $\mathrm{Qi}^{1, \mathrm{~d}}$ \\ ${ }^{1} \mathrm{Xi}$ 'an traffic engineering institute Xi'an, China
}

\begin{abstract}
The talent training scheme is the basis and principles for the implementation of professional personnel training, each college has a suitable environment around the professional orientation, students and the talent training scheme, this paper takes xi 'an institute of transportation engineering as an example, briefly expounds the university financial management professional undergraduate course major training service of ShaanXi economy development, radiation surrounding city high quality applied talents training target, in financial management professional talent training scheme to increase practice teaching modules, which incarnates the professional comprehensive practice ability of applied talents training target of some of the embodiment.
\end{abstract}

\section{INTRODUCTION}

Xi'an traffic engineering institute since 2017 the first financial management professional undergraduate students, from the start application Settings to this professional began to recruit students in this major, we this professional talent training scheme from the formulation, revision, and then make a lot of research study repeatedly, eventually in the related enterprises, under the guidance of experts and professors, combining with our school orientation of talent training, finally worked out the theory enough, big proportion of the practice teaching of our applied talents training of financial management professional talent training scheme.

\section{THE PRACTICE TEACHING MODULE CREDIT ARRANGEMENT IS REFLECTED IN THE TALENT TRAINING PROGRAM OF THIS SPECIALTY}

According to the orientation of the application-oriented undergraduate program, in the course of revising the talent training program for undergraduate financial management major, the practical teaching of this major is strengthened on the basis of ensuring the professional theoretical knowledge is sufficient. Practice teaching of this major is divided into in-class practice teaching module and concentrated practice teaching module, among which the credits of in-class practice teaching and theoretical courses are the same as 16 hours for 1 credit, and the credits of concentrated practice teaching for 1 week (no less than 30 hours) are 1 credit, and the credits of practice teaching module shall not be less than $25 \%$ of the total credits. It can be seen from the arrangement of credits of practical teaching modules that the college has increased the class hours of practical teaching without increasing the corresponding credits in order to highlight the practical ability of students of this major. In this way, the amount of practical teaching hours corresponding to each credit is enough to fully guarantee that students can complete the practical training courses related to their major with both quality and quantity guaranteed. Thus, the training program of this major is aimed at cultivating application-oriented undergraduate talents.

\section{THE PRACTICE TEACHING MODULE CURRICULUM SETTING IS REFLECTED IN THE TALENT TRAINING PROGRAM OF THIS SPECIALTY}

In accordance with the requirements of this professional school students practice ability, professional to adapt to the fast positioning, revision of this major in the talent training scheme in the curriculum of practice teaching modules according to the talent localization to carry on the strict screening, according to the quality of class teaching of undergraduate course of common colleges and universities national standard "requirement, combined with the actual situation of financial management specialty, summing up the core competence of professional financial management is: the investment and financing decision analysis, the ability to solve financial problems. Ability to acquire and process financial accounting information and financial data analysis and 
practical ability in the field of intelligent finance. In the talent training program, each kind of ability has the corresponding practice link teaching support, causes the core ability to be able to realize in the talent training.

The practical teaching module course of this major is designed from two aspects of practice in class and concentrated practice, taking practice in class and concentrated practice into account but not repeating each other, based on practice in class, the practice teaching course is set up on the principle of improving by concentrated practice. Among them, compulsory public courses, restricted courses of major direction and optional courses of major are set as in-class practice modules. The core courses of such majors as Comprehensive Accounting Training (Computerization), Basic Financial Management Training, VBSE Financial Virtual Simulation, Enterprise Cost Management Training, and Enterprise Tax Planning Training are set as centralized practice modules. Such a practice teaching module can not only ensure the students practice ability in the course of learning basic courses, but also ensure that students can improve their comprehensive practice ability by concentrating on practice after the theoretical study of core courses. In this way, the goal of cultivating talents with strong practical ability and quick career adaptation is finally reflected in the talent training program of this specialty As shown in the following table:

TABEL 1. Public Compulsory and Public Elective COURSES (Practice 12.5 CREDITS)

\begin{tabular}{|c|c|c|c|c|}
\hline The course name & $\begin{array}{c}\text { The } \\
\text { theory of } \\
\text { credit }\end{array}$ & $\begin{array}{c}\text { Practice } \\
\text { credit }\end{array}$ & $\begin{array}{c}\text { Theory } \\
\text { class } \\
\text { hours }\end{array}$ & $\begin{array}{c}\text { Practice } \\
\text { periods }\end{array}$ \\
\hline $\begin{array}{c}\text { Course Ideological } \\
\text { and moral } \\
\text { Cultivation and } \\
\text { Legal Basis }\end{array}$ & 2 & 1 & 32 & 16 \\
\hline $\begin{array}{c}\text { Outline of Modern } \\
\text { and Contemporary } \\
\text { Chinese history }\end{array}$ & 2 & 1 & 32 & 16 \\
\hline $\begin{array}{c}\text { Introduction to the } \\
\text { Basic Principles of } \\
\text { Marxism }\end{array}$ & 2 & 1 & 32 & 16 \\
\hline $\begin{array}{c}\text { MAO Zedong } \\
\text { Thought and An } \\
\text { Introduction to the } \\
\text { Theoretical System } \\
\text { of Socialism with } \\
\text { Chinese } \\
\text { Characteristics }\end{array}$ & 3 & 2 & 48 & 32 \\
\hline College EnglishA1 & 3.5 & 0.5 & 56 & 8 \\
\hline College EnglishA2 & 3.5 & 0.5 & 56 & 8 \\
\hline College EnglishA3 & 2.5 & 0.5 & 40 & 8 \\
\hline College EnglishA4 & 2.5 & 0.5 & 40 & 8 \\
\hline $\begin{array}{c}\text { Sports A1 } \\
\text { Sports A2 }\end{array}$ & 1 & 1 & 40 \\
\hline SportsA3 & & 1 & \\
\hline
\end{tabular}

\begin{tabular}{|c|c|c|c|c|}
\hline SportsA4 & & 1 & & 40 \\
\hline $\begin{array}{c}\text { University } \\
\text { Computer Base }\end{array}$ & & 1.5 & & 32 \\
\hline A combined & 35 & 12.5 & 564 & 290 \\
\hline
\end{tabular}

TABEL 2. Major ORIENTATION COURSE (PRACTICE 1.5 CREDIT)

\begin{tabular}{|c|c|c|c|c|}
\hline The course name & $\begin{array}{l}\text { The } \\
\text { theory } \\
\text { of credit }\end{array}$ & $\begin{array}{c}\text { Practice } \\
\text { credit }\end{array}$ & $\begin{array}{c}\text { Theory } \\
\text { class } \\
\text { hours }\end{array}$ & $\begin{array}{c}\text { Practice } \\
\text { periods }\end{array}$ \\
\hline $\begin{array}{c}\text { Accounting for } \\
\text { transportation } \\
\text { enterprises }\end{array}$ & 2.5 & 0.5 & 40 & 8 \\
\hline $\begin{array}{c}\text { Cost accounting of } \\
\text { transportation } \\
\text { enterprises }\end{array}$ & 2.5 & 0.5 & 40 & 8 \\
\hline $\begin{array}{c}\text { Financial } \\
\text { management of } \\
\text { transportation } \\
\text { enterprises }\end{array}$ & 2.5 & 0.5 & 40 & 8 \\
\hline $\begin{array}{c}\text { Fundamentals of } \\
\text { object-oriented } \\
\text { programming }\end{array}$ & 2.5 & 0.5 & 40 & 8 \\
\hline $\begin{array}{c}\text { Financial sharing } \\
\text { service }\end{array}$ & 2.5 & 0.5 & 40 & 8 \\
\hline $\begin{array}{c}\text { Visual analysis of } \\
\text { financial data }\end{array}$ & 2.5 & 0.5 & 40 & 8 \\
\hline A combined & 7.5 & 1.5 & 120 & 24 \\
\hline
\end{tabular}

TABEL 3. Optional COURSES (PRACTICE 1 CREDIT)

\begin{tabular}{|c|c|c|c|c|}
\hline The course name & $\begin{array}{l}\text { The } \\
\text { theory of } \\
\text { credit }\end{array}$ & $\begin{array}{c}\text { Practice } \\
\text { credit }\end{array}$ & $\begin{array}{c}\text { Theory } \\
\text { class } \\
\text { hours }\end{array}$ & $\begin{array}{c}\text { Practice } \\
\text { periods }\end{array}$ \\
\hline $\begin{array}{c}\text { Senior Financial } \\
\text { accountings }\end{array}$ & 2.5 & 0.5 & 40 & 8 \\
\hline $\begin{array}{c}\text { Science of auditing } \\
\text { Organizational } \\
\text { behavior }\end{array}$ & 2.5 & 0.5 & 40 & 8 \\
\hline Personal finance & 2.5 & 0.5 & 40 & 8 \\
\hline $\begin{array}{c}\text { Corporate finance } \\
\text { Financial } \\
\text { regulations and } \\
\text { accounting ethics }\end{array}$ & 2.5 & 0.5 & 40 & 8 \\
\hline A combined & 11 & 1 & 176 & 16 \\
\hline
\end{tabular}


TABEL 4. Intensive Practice COURSES (29.5 CREDITS OF PRACTICE)

\begin{tabular}{|c|c|c|}
\hline The course name & $\begin{array}{l}\text { Practice } \\
\text { credit }\end{array}$ & Practice periods \\
\hline Entrance education & 1 & 1 week \\
\hline The military training & 2 & 2 week \\
\hline Cognitive practice & 0.5 & 0.5 week \\
\hline $\begin{array}{c}\text { Comprehensive Simulation } \\
\text { training of Accounting } \\
\text { (Computerization) }\end{array}$ & 1.5 & 1.5 week \\
\hline Labor education & 1 & 1 week \\
\hline $\begin{array}{c}\text { ERP supply chain } \\
\text { management system training }\end{array}$ & 2 & 2 week \\
\hline $\begin{array}{l}\text { Basic training of enterprise } \\
\text { financial management }\end{array}$ & 1 & 1 week \\
\hline $\begin{array}{l}\text { VBSE financial virtual } \\
\text { simulation }\end{array}$ & 2 & 2 week \\
\hline $\begin{array}{c}\text { Enterprise cost management } \\
\text { training }\end{array}$ & 1 & 1 week \\
\hline $\begin{array}{l}\text { Enterprise tax planning } \\
\text { training }\end{array}$ & 1 & 1 week \\
\hline $\begin{array}{c}\text { Financial sharing virtual } \\
\text { simulation }\end{array}$ & 3 & 3week \\
\hline $\begin{array}{l}\text { Practical training of enterprise } \\
\text { financial report analysis }\end{array}$ & 1 & 1 week \\
\hline $\begin{array}{c}\text { Enterprise financial } \\
\text { management integrated virtual } \\
\text { simulation }\end{array}$ & 1 & 1 week \\
\hline Social practice & 2 & 2 week \\
\hline $\begin{array}{l}\text { Graduation (production) } \\
\text { internship }\end{array}$ & 2.5 & 5 week \\
\hline Graduation Project (Thesis) & 7 & 14 week \\
\hline A combined & 29.5 & 36week \\
\hline
\end{tabular}

Such a practice teaching module can not only ensure the students' practice ability in the course of learning basic courses, but also ensure that students can improve their comprehensive practice ability by concentrating on practice after the theoretical study of core courses. In this way, the goal of cultivating talents with strong practical ability and quick career adaptation is finally reflected in the talent training program of this specialty.

\section{THE EMBODIMENT OF THE PRACTICAL OPERATION MODE OF THE PRACTICAL TEACHING MODULE IN THE TALENT CULTIVATION SCHEME OF THIS SPECIALTY}

According to the school's training objectives of financial management major, such as cultivating talents with practical ability and team spirit, the practical teaching module of this major has its own emphasis in both in- class practice and concentrated practice. For in-class practice operation mode of practice teaching module mainly enterprise case study practice, related courses taught according to the difficult point of knowledge in the course syllabus collect related enterprise case, problems are put forward based on the case, lets the student group using the learned knowledge to discuss and analysis, finally guide the student to solve the problem, this is beneficial to students to master knowledge fast, will quickly into practice, but also can cultivate students' teamwork spirit. For module teaching practice courses, training their class teachers for centralized teaching respectively, can lead the students in this major at the university financial training center used accounting method, the comprehensive knowledge of professional knowledge, the process of enterprise financial work to begin operation, by focusing on the teaching, lets the student accordingly to the enterprise financial management, mainly includes the financial analysis, financial budget and financing management, investment management, working capital management and financial results distribution simulation training, let the students able to skillfully use all kinds of cost calculation method, improve the cost accounting of the actual operation ability, Consolidate the basic theoretical knowledge of accounting for the future work and learning to lay a foundation. As shown in the following table:

TABEL 5. PROFESSIONAL CORE COMPETENCE AND REALIZATION APPROACHES

\begin{tabular}{|c|c|c|}
\hline The serial number & $\begin{array}{l}\text { Professional core } \\
\text { Competence }\end{array}$ & Practice periods \\
\hline 1 & $\begin{array}{l}\text { Ability to analyze } \\
\text { investment and financing } \\
\text { decisions and solve } \\
\text { financial problems. } \\
\text { Ability to acquire and } \\
\text { process financial } \\
\text { accounting information } \\
\text { and financial data } \\
\text { analysis and practical } \\
\text { ability in the field of } \\
\text { intelligent finance. }\end{array}$ & $\begin{array}{l}\text { Basic training of } \\
\text { enterprise financial } \\
\text { management,VBSE } \\
\text { comprehensive } \\
\text { financial training, } \\
\text { Practical training of } \\
\text { enterprise financial } \\
\text { report analysis, } \\
\text { Comprehensive } \\
\text { simulation training of } \\
\text { enterprise financial } \\
\text { management. }\end{array}$ \\
\hline \multirow[t]{2}{*}{2} & $\begin{array}{l}\text { Ability to acquire and } \\
\text { process financial } \\
\text { accounting information } \\
\text { and financial data } \\
\text { analysis and practical } \\
\text { ability in the field of } \\
\text { intelligent finance. }\end{array}$ & $\begin{array}{c}\text { Training in } \\
\text { Enterprise Cost } \\
\text { Management, } \\
\text { Training in Enterprise } \\
\text { Tax Planning, } \\
\text { Training in Enterprise } \\
\text { Simulation } \\
\text { Accounting } \\
\text { Comprehensive } \\
\text { Simulation, Training } \\
\text { in Enterprise } \\
\text { Financial Report } \\
\text { Analysis }\end{array}$ \\
\hline & & \\
\hline
\end{tabular}




\section{THE EFFECT ACHIEVED BY THE PRACTICE TEACHING MODULE IS REFLECTED IN THE TALENT TRAINING PROGRAM OF THIS SPECIALTY}

The ultimate goal of the financial management professional training in our school is to train compound application-oriented talents who are capable of accounting, tax planning, financing, investment and capital operation of enterprises and institutions. In order to better realize the talent training goal of this major, the practice of this major carries out practical teaching according to the progressive mode of "cognition, basic skills, special skills and comprehensive skills". The revised talent training plan for 2019 lays more emphasis on practical teaching and is more specific. The practice hours of compulsory courses are 42 credits, and the practice hours of elective courses are 4.5 credits. There are 12 courses offering in-class practical training. There are 11 intensive practice links, in addition, labor education for 1 week, social practice for 2 weeks, graduation practice for 5 weeks, and graduation design for 14 weeks. In-class practical training, extracurricular practice and concentrated practice are carried out comprehensively, and both in-class and extracurricular activities are taken into account. From enrollment to graduation, the practice teaching of "wholeprocess, hierarchical and progressive" is realized.

Therefore, in the course system setting of this major, especially the teaching setting of comprehensive practice course has made full preparation. For example, the accounting computerization comprehensive practice, comprehensive practice of accounting, the cost management training, etc., the purpose is mainly through the simulation enterprise operating normally, accounting personnel to the company occurred in the business activities of the economic business accounting and supervision, is a student can enter the job role as soon as possible after graduation. Tax Planning Simulation Training is mainly used to simulate the tax-related work of enterprises through tax software, which enables students to make reasonable plans for enterprises' tax paying behavior after entering the enterprises in the future. Comprehensive Training on Financial Management Cases, Comprehensive Training on Investment and Risk Management, etc., are mainly aimed at cultivating students' abilities of financing, investment and capital operation, so as to better reflect the composite application-oriented training objectives of students in this major.

\section{THE GUARANTEE SYSTEM OF PRACTICAL TEACHING MODULE}

In accordance with the "outstanding practice teaching, cultivating students' comprehensive quality of personnel training requirements, combining with our school applied talents training goal and the requirements of medium and long-term development planning, in order to cultivate applied talents with financial comprehensive practice and innovation ability as the goal, to build a realistic financial system environment, causes the student to simulate the whole process of enterprise financial processing, the school in the process of financial management professional construction, construction of schools for the professional training rooms larger funding, from innovation business infrastructure as a starting point, to establish new type of practice teaching in our school have a concession characteristic base" financial can comprehensive training center ", We will effectively assist entrepreneurship and innovation bases in training all-round entrepreneurship and innovation talents. The training base consists of two parts: THE VBSE financial informatization competition platform and the VBSE financial comprehensive training platform. Based on V2.1 of XinDao VBSE financial practice teaching platform and cloud financial technology, practical training courses are developed to provide practical teaching platform for students. It can not only ensure the practical teaching of students of this major, but also experience the role of the position in the enterprise.

\section{THE SUMMARY}

In short, in today's China's employment pressure and unit of choose and employ persons prefer to hire employees practice ability of the environment, our university financial management professional talent training scheme is aimed at the actual conditions and formulating, aims to develop to meet the need of regional economic and social development of morality, intelligence and physique, us, fatigue all-round development, master the accounting and financial management skills, have financial data processing, analysis of financial information and financial decision-making services such as professional ability and a higher level of foreign language, communication ability, cooperation ability and innovation ability, High-quality applied talents who can be engaged in accounting, financial forecasting, decision-making and analysis, tax planning, risk management, asset evaluation, financial intelligent data processing and other work in the transportation industry and other enterprises and institutions. Such a talent training goal not only conforms to the professional quality and skill orientation of financial management talents in our school, but also meets the requirements of employers for financial talents.

\section{ACKNOWLEDGMENT}

2019 Education and Teaching Reform research project of Xi'an traffic engineering institute "Research on The Practical Teaching System of Financial Management Specialty based on Ability in Private Colleges" (project code: 1910601) Phased achievements.

\section{REFERENCES}

1. Qin Jialong, and $\mathrm{Mu} \mathrm{Li}$."Research on the Training Mode of Application-oriented innovative Talents in accounting Under the background of big data," 
Education and Teaching Forum, Shi Jiazhuang, pp. 104-106, September 2020.

2. Li Xuemei. "Discussion on the training scheme of professional undergraduates in engineering cost specialty," Anhui building, He Fei , pp. 123+158, October 2020.

3. Yu Guilin. "Principles of practical Teaching System construction for applied Tourism Management undergraduate major," Modernization of education, Bei Jing, pp. 127-130, July 2020.

4. Jiang Wenfeng. "On the Construction of practice Teaching system of "Three Innovations" in application-oriented universities," Innovation and entrepreneurship education, Chang Sha, pp. 136-140, June 2020.

5. Liu Peipei. "Research on the Construction of undergraduate Practical Teaching System for engineering Cost Specialty," Residential and Real Estate, Shen Zhen, pp. 255-256, May 2020.

6. Feng Chunyang. "An Inquiry into the Construction of practical Teaching System for applied Undergraduate Auditing Major -- A Case study of Sichuan University of Business and Economics," Fortune Today, Hohhot, pp. 211-212, May 2020. 